\title{
Üniversitede öğrenim gören kız öğrencilerin HPV bilgi düzeyinin incelenmesi (Sakarya, Türkiye)
}

\author{
Investigation of the university female students knowledge on the HPV \\ (Sakarya, Turkey)
}

Kevser Özdemir®, Sevil Șahin²®, Alaettin Ünsal®

\section{öz}

AMAC̦: Üniversite öğrencilerinin HPV hakkında bilgi düzeylerinin saptanmasıdır.

GEREÇ ve YÖNTEMLER: Çalışma, Eylül-Kasım 2015 tarihleri arasında Sakarya Üniversitesi öğrencileri üzerinde gerçekleştirilen kesitsel tipte bir araştırmadır. Çalışma süresince okulda bulunan ve çalışmaya katılmayı kabul eden 618 öğrenci çalışma grubunu oluşturmuştur. Analizler için Mann-Whitney U testi, Kruskal Wallis testi ve Spearman Korelasyon Analizi kullanıldı. İstatistiksel anlamlılık için $\mathrm{p} \leq 0,05$ kabul edildi.

BULGULAR: Çalışma grubunu oluşturanların yaşları 18-30 arasında değişmekte olup, ortalama 20,21 $\pm 1,77$ yl idi. Bu çalışmada HPV ile ilgili olarak en çok doğru bilinen bilgi sorusu "Genital bölgede hijyenik olmayan işlemler HPV bulaş riskini artırır" iken, en çok yanlış bilinen ise "HPV enfeksiyonu doğurganlığı doğrudan etkilemez" bilgi sorusu olmuştur. Öğrencilerin HPV ile ilgili bilgi sorularından aldıkları puanlar

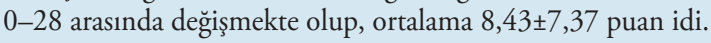

SONUÇ: Bu çalışmada öğrencilerin HPV hakkındaki bilgi düzeylerinin düşük olduğu görülmüştür. Öğrencilerin akademik not ortalamaları ile HPV bilgi düzeyleri arasında bir ilişki yoktur. Üniversitelerde sağlıkla ilgili derslere yer verilmesi ve bu derslerde HPV hakkında da bilgi verilmesi yararlı olabilir. Ayrıca HPV hakkında belli aralıklarla bilgilendirme çalışmalarının yapılması bu konudaki duyarlılığı ve farkındalığı arttıracaktır.

Anahtar kelimeler: HPV, bilgi düzeyi, üniversite kız öğrencisi, Sakarya

\section{GíRiș}

Human Papilloma Virüs (HPV) genellikle genital siğile neden olan ve cinsel yolla bulaşan bir virüstür. Cinsel yönden aktif bireylerde ilişki sırasında korunma (prezervatif)

'Sakarya Üniversitesi, Sağlık Bilimleri Fakültesi, Sakarya, Türkiye

${ }^{2}$ Ankara Yıldırım Üniversitesi, Sağık Bilimleri Fakültesi, Ankara, Türkiye

${ }^{3}$ Eskişehir Osmangazi Üniversitesi Tıp Fakültesi, Eskişehir, Türkiye

Yazışma Adresi/ Correspondence:

Dr. Öğr. Üyesi Kevser Özdemir

Sakarya Üniversitesi, Sağlık Bilimler Fakültesi, 54187, Sakarya, Türkiye

Tel: $\quad$ +905072354102

E-mail: kevserozdemir@sakarya.edu.tr

Gelis/ Received: $\quad 12.10 .2020$

Kabul/ Accepted: $\quad 23.12 .2020$

\section{ABSTRACT}

OBJECTIVE: To determine the level of knowledge of university students about HPV.

MATERIAL and METHODS: The study is a cross-sectional study conducted on Sakarya University students between SeptemberNovember 2015. The study group consisted of 618 female students who agreed to participate in the study and were in the school during the study. Mann-Whitney U test, Kruskal-Wallis test and Spearman's Correlation Analysis were used for the analyses. The statistical significance level was accepted as $\mathrm{p}<0.05$.

RESULTS: The age of the study group ranged from 18 to 30 , with a mean of $20.21 \pm 1.77$ years. In this study, the most commonly known information question about HPV was "Unhygienic procedures increase the risk of HPV transmission in the genital area", while the most commonly misknown was "HPV infection does not directly affect fertility" information question. The scores that students got from knowledge questions about HPV ranged from 0 to 28 , and the mean was $8.43 \pm 7.37$.

CONCLUSION: In this study, it was seen that students' knowledge level about HPV was low. There is no relationship between students' academic grade averages and HPV knowledge levels. It may be useful to include health-related courses in universities and to provide information about HPV in these courses. Also, informing about the HPV periodically will increase the sensitivity and awareness on this issue.

Keywords: HPV, knowledge level, university female student, Sakarya

sağlanmamışsa bulaş çok sık gözlenmektedir. Dünya genelinde HPV çok yaygın bir şekilde görülmektedir. ${ }^{[1]}$ İnsanda hastalık yapan HPV tipleri, anogenital siğilden kansere kadar çeşitli lezyonlardan sorumlu tutulmaktadır. HPV tip 6 ve 11 anogenital siğillerin \%90'dan fazlasından sorumludur. HPV tip 16 ve 18 insanlarda kansere yol açmakta, tip 31 ve 33 ise muhtemelen karsinojenik olduğu düşünülmektedir. Servikal kanserlerde tip 16 en sık görülen HPV virüs tipi olup, bütün servikal kanserlerin $\% 53,5$ 'inde saptanır. HPV tip 18 ikinci sıklıkta görülüp, \%17,2'sini oluşturur. Yalnızca HPV Tip 16 ve 18 ikisi birlikte tüm servikal kanserlerin \%70'sinden fazlasından sorumludur. Daha sonra HPV 45 (\%6,7), HPV $31(\% 2,9)$, HPV 33 $(\% 2,6), 52(\% 2,3), 56(\% 2,2)$ tipleri görülür. ${ }^{[2]}$ 
HPV virüsü bulaştıktan sonra \%70'i bir yıl içinde, \%90'1 ise 2 yll içinde vücuttan temizlenmektedir. Yüzde onluk kısım düşük riskli lezyonlara yol açan HPV tip 6 ve 11 tarafindan oluşturulan genital siğile dönüşmektedir. HPV tip 16 ve 18 tarafından oluşturulan \%2'lik kısmı ise kanser öncesi lezyonlara ve tedavi edilmediği taktirde kanserlere yol açmaktadır. Servikal kanser ve vulvar kanserin etiyolojisinde rol oynadığı litertürdeki çalışmalarla belirlenmiştir. ${ }^{[3-5]}$

Human Papilloma Virüs ile ilişkisi kanıtlanan servikal kanser ise dünyada kadınlarda en sık görülen 3. kanserdir. Kadınlarda kansere bağlı ölümlerin \%1,6'sı ve jinekolojik tümörlere bağlı ölümlerin \%15’i serviks kanserine bağlıdır. ${ }^{[6]}$ Türkiye, serviks kanseri insidansının en düşük olduğu Batı Asya grubu ülkeleri içinde yer almaktadır. [7] Ülkemizde 2014 verilerine göre, kadın kanserlerinin \%2,4’ünü serviks kanseri oluşturmaktadır. Kadınlarda görülen kanserler arasında 9. sırada, jinekolojik kanserler arasında ise 3. sıradadır. ${ }^{\left[{ }^{[]}\right.}$

HPV nedenli serviks kanserine karşı en etkili koruma profilaktik HPV aşıııdır. İlk cinsel ilişkiden önce yapılması gereken HPV aşısının uygulanma durumu çeşitli nedenlere bağlı olarak düşüktür. ${ }^{[9,10]}$ Toplumumuzda aşının yan etkileri ve güvenilirliği, etkililiği, maliyeti ve cinsel aktiviteyi artıracağı şeklinde kaygılar bulunmaktadır. ${ }^{[1]]} \mathrm{Bu}$ nedenle sağlık personeli HPV enfeksiyonu ve aşısı ile ilgili toplumu bilgilendirmek, var olan yanlış bilgileri düzeltmek ve bireylerin bilgi sahibi olarak aşı yaptırıp yaptırmamaya karar vermelerini sağlamak açısından önemli bir konumdadır. ${ }^{[12]}$ Ayrıca üniversite döneminde öğrenciler HPV enfeksiyonu ve komplikasyonları açısından risk altındadır. Bu yönlerden bakıldığında üniversite öğrencileri genç oldukları için HPV açısından risk grubunda olmaları nedeniyle, HPV enfeksiyonu ve aşıları konusunda yeterli bilgi sahibi olması gereken önemli bir gruptur. ${ }^{[13]} \mathrm{Bu}$ çalışma ile üniversite öğrencilerinin HPV hakkındaki bilgi düzeylerinin saptanması ve ilişkili olduğu düşünülen bazı değişkenlerin incelenmesi amaçlanmıştır.

\section{GEREÇ Ve YÖNTEMLER}

Bu çalışma, Eylül- Kasım 2015 tarihleri arasında Sakarya üniversitesi kız öğrencileri üzerinde yapılan bir kesitsel tipte bir araştırmadır. Çalışmanın evrenini Sakarya Üniversitesi bünyesinde Eylül- Kasım 2015 tarihleri arasında lisans eğitimi gören kız öğrenciler oluşturmaktadır. Bu çalışma için ulaşılması gereken minimum öğrenci sayısı minitab 16 istatistik paket programı yardımıyla 600 olarak hesaplanmıştır (standard deviation: 1,0, difference: 0,13 , alpha: $0,05$, power of test: 0,89$)$. Fakülteler ise, kampüs içerisinde eğitim veren 16 adet fakülteden zarf yöntemi ile Sağlık Bilimleri Fakültesi, Fen-Edebiyat Fakültesi, Mühendislik
Fakütesi ve İktisadi ve İdari Bilimler Fakütesi olarak belirlendi. Ardından her bir gruptan seçilen toplam $618 \mathrm{kız}$ öğrenci çalışma grubunu oluşturdu.

Araştırmanın yürütülebilmesi için gerekli izinler alındı (17.09.2014 tarih ve 30579404/044 say1). Ayrıca, veri toplanmadan önce de her bir fakültenin dekanlığından gerekli yazılı izinler alındı. Çalışmanın konusu ve amacı hakkında öğrencilere bilgi verildi ve öğrencilerin onamları alındıktan sonra, önceden hazırlanmış anket formları, gözetim altındaki ögrenciler tarafından sınıf ortamında dolduruldu. Veri toplama aşamasında Helsinki Bildirgesi'nde belirtilen kurallara uyuldu.

Bu çalışmada öğrencilerin HPV hakkındaki bilgi düzeylerinin değerlendirilmesi amacıyla literatürden de faydalanılarak bir anket form hazırland.. ${ }^{[2,11-14]} \mathrm{Bu}$ anket form öğrencilerin bazı özelliklerini (yaşı, fakülte adı, sınıfı, yerleşim yeri, mezun olduğu lise, anne-baba öğrenim ve çalışma durumu, aile tipi, aile gelir durumu, kaldığı yer), HPV bilgi düzeyi ile ilişkili olduğu düşünülen bazı faktörleri (öğrenim görmekte olduğu bölümü isteme durumu, akademik not ortalaması, virüslerle kanser ilişkisi, HPV hakkında önceden bilgi sahibi olma durumu, HPV aşısı hakkında önceden bilgi sahibi olma durumu ve HPV aşıs1 olma durumu) ve 35 tane HPV ile ilgili bilgi sorusunu içermektedir. Anket formda yer alan HPV ile ilgili bilgi sorularının değerlendirilmesinde doğru bilinen her soruya "1" puan verildi. Öğrencilerin alacakları puanlar 0-35 arasında değişmektedir. Bilgi sorularından alınan puanlar arttıkça HPV bilgi düzeyi de artmaktadır.

Elde edilen veriler, IBM SPSS (versiyon 20.0) İstatistik Paket Programında değerlendirilmiştir. Verilerin normal dağılıma uygunluğu Shapiro-Wilk testi ile yapılmıştır. Analizler için Mann-Whitney U testi, Kruskal-Wallis testi ve Spearman's Korelasyon testi kullanılmıştır. İstatistiksel anlamlılık değeri olarak $\mathrm{p}<0,05$ kabul edilmiştir.

\section{BULGULAR}

Çalışma grubunu oluşturanların yaşları 18-30 arasında değişmekte olup, ortalama $20,21 \pm 1,77$ yl idi. Öğrencilerin 102'si (\%16,5) 18 yaşında, 117'si (\%18,9) 19 yaşında, 156 'sı $(\% 25,2) 20$ yaşında, 129'u $(\% 20,9) 21$ yaşında, 114 ü $(\% 18,4)$ ise 22 ve üzeri yaş grubundadır. Çalışma grubundakilerin 294'ü $(\% 47,6)$ Düz Lise'den, 196's1 $(\% 31,7)$ Anadolu Lisesi’nden, 49'u $(\% 7,9)$ Sağlık Meslek Lisesi'nden, 79'u $(\% 12,8)$ ise diğer liselerden mezun olmuşlardır. Aile gelir durumunu orta düzeyde olduğunu bildiren öğrenci sayısı $443(\% 71,7)$ idi. Öğrencilerden 482 'si $(\% 78,0)$ çekirdek tipi aile yapısına sahiptir. Yurtta kalanların sayısı $448(\% 72,5)$ idi. 
Bu çalışmada HPV ile ilgili olarak en çok doğru bilinen bilgi sorusu \%58,7 ile "Genital bölgede hijyenik olmayan işlemler HPV bulaş riskini artırır” iken, en çok yanlış bilinen ise \%22,5 ile "HPV enfeksiyonu doğurganlığı doğrudan etkilemez" bilgi sorusu idi. Öğrencilerin HPV hakkındaki sorulara verdikleri cevapların dağılımı Tablo 1'de gösterilmiştir.
Öğrencilerin HPV ile ilgili bilgi sorularından aldıkları puanlar 0-28 arasında değişmekte olup, ortalama $8,43 \pm 7,37$ puan idi. Çalışma grubundakilerin HPV ile ilgili bilgi sorularından aldıkları ortanca puanların bazı sosyo-demografik özelliklere göre dağılımı Tablo 2'de verilmiştir.

Tablo 1. Öğrencilerin HPV ile ilgili bilgi sorularına verdikleri cevapların dağılımı

\begin{tabular}{|c|c|c|c|}
\hline HPV ile ilgili bilgi soruları & Doğru n (\%) & Yanlışn (\%) & Fikrim yok $n(\%)$ \\
\hline HPV, genital siğillere neden olan bir mikroorganizmadır & $178(28,8)$ & $13(2,1)$ & $427(69,1)$ \\
\hline Ailede serviks kanseri öyküsü bir risk faktörüdür. & $296(47,9)$ & $43(7,0)$ & $279(45,1)$ \\
\hline Genital bölgede hijyenik olmayan işlemler HPV bulaş riskini artırır. & $363(58,7)$ & $12(1,9)$ & $243(39,3)$ \\
\hline HPV enfeksiyonu serviks kanseri riskini artırır. & $274(44,3)$ & $18(2,9)$ & $326(52,8)$ \\
\hline *HPV enfeksiyonuna karşı etkili bir aşı yoktur. & $30(4,9)$ & $199(32,2)$ & $389(62,9)$ \\
\hline *Genital bölgedeki tüm siğiller serviks kanseri nedenidir & $64(10,4)$ & $153(24,8)$ & $401(64,9)$ \\
\hline HPV ile enfekte olan her bireyde şikâyet olmaz. & $62(10,0)$ & $102(16,5)$ & $454(73,5)$ \\
\hline Cinsel partner fazlalılığı serviks kanseri riskini artırır. & $284(46,0)$ & $26(4,2)$ & $308(49,8)$ \\
\hline Cinsel partneri çok olanlarla ilişki yaşamak serviks kanseri riskini artırır. & $299(48,4)$ & $24(3,9)$ & $295(47,7)$ \\
\hline HPV enfeksiyonu doğurganlığı doğrudan etkilemez. & $56(9,1)$ & $139(22,5)$ & $423(68,4)$ \\
\hline Kondom kullanımı serviks kanseri riskini azaltır. & $170(27,5)$ & $48(7,8)$ & $400(64,7)$ \\
\hline Sigara, serviks kanseri riskini artırır. & $206(33,3)$ & $41(6,6)$ & $371(60,0)$ \\
\hline Erken gebelik, HPV enfeksiyonu için bir risktir. & $109(17,6)$ & $50(8,1)$ & $459(74,3)$ \\
\hline *3'den fazla gebelik, serviks kanseri riskini artırır. & $132(21,4)$ & $50(8,1)$ & $436(70,6)$ \\
\hline Serviks kanserinden korunmada HPV aşısı etkilidir. & $189(30,6)$ & $28(4,5)$ & $401(64,9)$ \\
\hline *HPV aşıSı ömür boyu koruyucudur. & $60(9,7)$ & $79(12,8)$ & $479(77,5)$ \\
\hline Serviks kanserinde erken tanı ve tedavi mümkündür. & $254(41,1)$ & $26(4,2)$ & $338(54,7)$ \\
\hline *Cinsel yönden aktif olan her kadın PAP-Smear testi yaptırmalıdır. & $228(36,9)$ & $19(3,1)$ & $371(60,0)$ \\
\hline *HPV enfeksiyonu tedavisinde antibiyotikler etkilidir. & $51(8,3)$ & $76(12,3)$ & $491(79,4)$ \\
\hline PAP-Smear testinin hayat boyu 1 kez yaptırılması yeterli değildir. & $159(25,7)$ & $44(7,1)$ & $415(67,2)$ \\
\hline Serviks kanseri kesin tanısı PAP-Smear ile konulmaz. & $96(15,5)$ & $60(9,7)$ & $462(74,8)$ \\
\hline Serviks kanseri en sık 35-55 yaş grubunda görülür. & $155(25,1)$ & $28(4,5)$ & $435(70,4)$ \\
\hline $\begin{array}{l}\text { *Adet araları ve cinsel ilişki sonrası görülen anormal kanamalar, serviks } \\
\text { kanserinin erken belirtilerindendir. }\end{array}$ & $163(26,4)$ & $26(4,2)$ & $429(69,4)$ \\
\hline HPV aşısı sadece kız çocuklara yapılır. & $94(15,2)$ & $89(14,4)$ & $435(70,4)$ \\
\hline *PAP-Smear, jinekolojik şikâyeti olanlara yapılmalıdır. & $61(9,9)$ & $143(23,1)$ & $414(67,0)$ \\
\hline *Serviks kanseri, erken dönemde bulgu verir. & $109(17,6)$ & $92(14,9)$ & $417(67,5)$ \\
\hline *Genital bölge siğilleri zararsızdır, kendiliğinden iyileşir & $43(7,0)$ & $232(37,5)$ & $343(55,5)$ \\
\hline Genital bölge siğilleri kötü huylu olabilir, tanı için biyopsi gerekir. & $234(37,9)$ & $20(3,2)$ & $364(58,9)$ \\
\hline Toplumun \%70’i HPV ile enfektedir. & $55(8,9)$ & $42(6,8)$ & $521(84,3)$ \\
\hline HPV aşısı 9-26 yaş grubuna uygulanır. & $76(12,3)$ & $58(9,4)$ & $484(78,3)$ \\
\hline HPV aşısı her yıl tekrarlanmak zorunda değildir. & $55(8,9)$ & $53(8,6)$ & $510(82,5)$ \\
\hline *Kadınlarda kanser nedeniyle ölümlerinin ilk sırasında serviks kanseri yer alır. & $114(18,4)$ & $84(13,6)$ & $420(68,0)$ \\
\hline *Serviks kanseri olanlarda uterus tamamen alınır. & $59(9,5)$ & $134(21,7)$ & $425(68,8)$ \\
\hline HPV enfeksiyonu tuvaletten bulaşabilen bir hastalıktır. & $74(12,0)$ & $99(16,0)$ & $445(72,0)$ \\
\hline HPV enfeksiyonu öksürme ve hapşırma ile bulaşmaz. & $185(29,9)$ & $50(8,1)$ & $383(62,0)$ \\
\hline *, yanlış önerme. & & & \\
\hline
\end{tabular}


Tablo 2. Çalışma grubundakilerin HPV ile ilgili bilgi sorularından aldıkları ortanca puanların bazı sosyo-demografik özelliklere göre dağılımı

\begin{tabular}{|c|c|c|c|c|c|}
\hline Sosyo-demografik özellikler & $n$ & $\begin{array}{c}\text { HPV bilgi puanı } \\
\text { Median (min-max) }\end{array}$ & $\begin{array}{l}\text { Test değeri } \\
z / K W ; p\end{array}$ & $\begin{array}{c}\text { Çoklu } \\
\text { karşılaştırma }\end{array}$ & $p$ \\
\hline \multicolumn{6}{|l|}{ Okulu } \\
\hline Sağıık Yüksekokulu (1) & 152 & $15,0(0,0-28,0)$ & \multirow{6}{*}{77,$993 ; 0,000$} & $1-2$ & 0,000 \\
\hline Fen Edebiyat Fakültesi (2) & 193 & $6,0(0,0-21,0)$ & & $1-3$ & 0,000 \\
\hline İktisadi İdari Bilimler F. (3) & 187 & $3,0(0,0-23,0)$ & & $1-4$ & 0,002 \\
\hline Mimarlık-Mühendislik F (4) & 86 & $9,0(0,0-24,0)$ & & $2-3$ & 1,000 \\
\hline- & - & - & & $2-4$ & 0,118 \\
\hline- & - & - & & $3-4$ & 0,016 \\
\hline \multicolumn{6}{|l|}{ Yaş grubu } \\
\hline 18 & 102 & $8,2(0,0-28,0)$ & \multirow{5}{*}{7,$193 ; 0,126$} & - & - \\
\hline 19 & 117 & $6,8(0,0-24,0)$ & & - & - \\
\hline 20 & 156 & $9,6(0,0-25,0)$ & & - & - \\
\hline 21 & 129 & $8,6(0,0-22,0)$ & & - & - \\
\hline 22 ve üzeri & 114 & $8,4(0,0-25,0)$ & & - & - \\
\hline \multicolumn{6}{|c|}{ Yaşamının çoğunu geçirdiği yerleşim yeri } \\
\hline Köy & 70 & $6,0(0,0-25,0)$ & \multirow{3}{*}{0,$016 ; 0,992$} & - & - \\
\hline ilcçe merkezi & 178 & $8,0(0,0-23,0)$ & & - & - \\
\hline İl merkezi & 370 & $8,0(0,0-28,0)$ & & - & - \\
\hline \multicolumn{6}{|l|}{ Mezun olduğu lise } \\
\hline Düz Lise (1) & 294 & $8,0(0,0-25,0)$ & \multirow{6}{*}{29,$030 ; 0,000$} & $1-2$ & 1,000 \\
\hline Anadolu Lisesi (2) & 196 & $7,0(0,0-24,0)$ & & $1-3$ & 0,000 \\
\hline Sağlık Meslek Lisesi (3) & 49 & $18,0(0,0-28,0)$ & & $1-4$ & 1,000 \\
\hline Diğer Liseler (4) & 79 & $6,0(0,0-23,0)$ & & $2-3$ & 0,000 \\
\hline- & - & - & & $2-4$ & 1,000 \\
\hline- & - & - & & $3-4$ & 0,000 \\
\hline \multicolumn{6}{|l|}{ Anne öğrenim durumu } \\
\hline İlkokul ve alt & 505 & $8,0(0,0-28,0)$ & \multirow{2}{*}{1,$398 ; 0,162$} & - & - \\
\hline Ortaokul ve üzeri & 113 & $7,0(0,0-22,0)$ & & - & - \\
\hline \multicolumn{6}{|l|}{ Baba öğrenim durumu } \\
\hline illkokul ve alt & 368 & $8,0(0,0-25,0)$ & \multirow{2}{*}{1,$185 ; 0,236$} & - & - \\
\hline Ortaokul ve üzeri & 250 & $8,0(0,0-28,0)$ & & - & - \\
\hline \multicolumn{6}{|l|}{ Aile tipi } \\
\hline Çekirdek (1) & 482 & $8,0(0,0-25,0)$ & & - & - \\
\hline Geniş (2) & 122 & $6,0(0,0-28,0)$ & 1,$968 ; 0,374$ & - & - \\
\hline Parçalanmış (3) & 14 & $5,0(0,0-22,0)$ & & - & - \\
\hline \multicolumn{6}{|l|}{ Aile gelir durumu } \\
\hline Kötü (1) & 134 & $6,5(0,0-25,0)$ & & $1-2$ & 0,798 \\
\hline Orta (2) & 443 & $8,0(0,0-28,0)$ & 7,$199 ; 0,027$ & $1-3$ & 0,246 \\
\hline İyi (3) & 41 & $5,0(0,0-19,0)$ & & $2-3$ & 0,030 \\
\hline \multicolumn{6}{|l|}{ Kaldığı yer } \\
\hline Ailesi ile birlikte & 99 & $5,0(0,0-28,0)$ & & - & - \\
\hline Yurtta & 448 & $8,0(0,0-25,0)$ & $0,861,0,650$ & - & - \\
\hline Evde arkadaşları ile birlikte & 71 & $8,0(0,0-23,0)$ & & - & - \\
\hline Toplam & 618 & $8,0(0,0-28,0)$ & - & - & - \\
\hline
\end{tabular}


Tablo 3. Öğrencilerin HPV ile ilgili bilgi sorularından aldıkları ortanca puanların HPV bilgi düzeyi ile ilişkili olduğu düşünülen bazı özelliklere göre dağılımı

\begin{tabular}{|c|c|c|c|}
\hline HPV bilgi düzeyi ile ilişkili bazı özellikler & $n$ & $\begin{array}{l}\text { HPV bilgi puanı } \\
\text { Median (min-max) }\end{array}$ & Test değeri $z ; p$ \\
\hline \multicolumn{4}{|c|}{ Öğrenim görmekte olduğu bölümü isteme durumu } \\
\hline İstemiyor & 192 & $7,0(0,0-23,0)$ & \multirow{2}{*}{1,$125 ; 0,260$} \\
\hline İstiyor & 426 & $8,0(0,0-28,0)$ & \\
\hline \multicolumn{4}{|c|}{ Öğrenim görmekte olduğu bölümü değiştirmeyi isteme durumu } \\
\hline İstemiyor & 425 & $7,0(0,0-25,0)$ & \multirow{2}{*}{1,$876 ; 0,061$} \\
\hline İstiyor & 193 & $9,0(0,0-28,0)$ & \\
\hline \multicolumn{4}{|c|}{ Bazı virüslerin kansere neden olduğunu bilme durumu } \\
\hline Bilmiyor & 76 & $5,0(0,0-22,0)$ & \multirow{2}{*}{1,$439 ; 0,150$} \\
\hline Biliyor & 542 & $8,0(0,0-28,0)$ & \\
\hline \multicolumn{4}{|c|}{ HPV virüsü hakkında önceden bilgi sahibi olma durumu } \\
\hline Hayır & 288 & $3,0(0,0-24,0)$ & \multirow{2}{*}{10,$210 ; 0,00$} \\
\hline Evet & 330 & $13,0(0,0-28,0)$ & \\
\hline \multicolumn{4}{|c|}{ HPV virüsünün serviks kanserine neden olduğunu bilme durumu } \\
\hline Bilmiyor & 198 & $4,0(0,0-24,0)$ & \multirow{2}{*}{10,$850 ; 0,000$} \\
\hline Biliyor & 420 & $14,0(0,0-28,0)$ & \\
\hline \multicolumn{4}{|c|}{ HPV aşısı hakkında önceden bilgi sahibi olma durumu } \\
\hline Bilmiyor & 452 & $5,0(0,0-28,0)$ & \multirow{2}{*}{8,$832 ; 0,000$} \\
\hline Biliyor & 166 & $14,5(0,0-25,0)$ & \\
\hline \multicolumn{4}{|l|}{ HPV aşısı olma isteği } \\
\hline İstemiyor & 431 & $7,0(0,0-25,0)$ & \multirow{2}{*}{3,$174 ; 0,002$} \\
\hline İstiyor & 187 & $11,0(0,0-28,0)$ & \\
\hline Toplam & 618 & $8,0(0,0-28,0)$ & - \\
\hline
\end{tabular}

Çalışma grubundakilerden 426’sı $(\% 68,9)$ öğrenim görmekte olduğu bölüme isteyerek devam ettiğini, 542'si $(\% 87,7)$ bazı virüslerin kansere neden olduğu hakkında bilgi sahibi olduğunu, 330’u $(\% 53,4)$ HPV virüsü hakkında önceden bilgi sahibi olduğunu, 431'i (\%69,7) HPV aşısı olmak istemediğini bildirmiştir. Öğrencilerin HPV ile ilgili bilgi sorularından aldıkları ortanca puanların HPV bilgi düzeyi ile ilişkili olduğu düşünülen bazı özelliklere göre dağılımı Tablo 3'de verilmiştir.

$\mathrm{Bu}$ çalışmada öğrencilerin akademik not ortalamala-

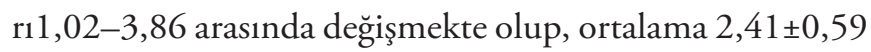
idi. Çalışma grubundakilerin akademik not ortalamaları ile HPV bilgi değerlendirme sorularından aldıkları puanlar arasında bir ilişki saptanamamıştır $\left(r_{s}=-0,016 ; p=0,751\right)$. Öğrencilerin akademik not ortalamaları ile HPV bilgi değerlendirme sorularından aldıkları puanların dağılımı Grafik 1'de gösterilmiştir.

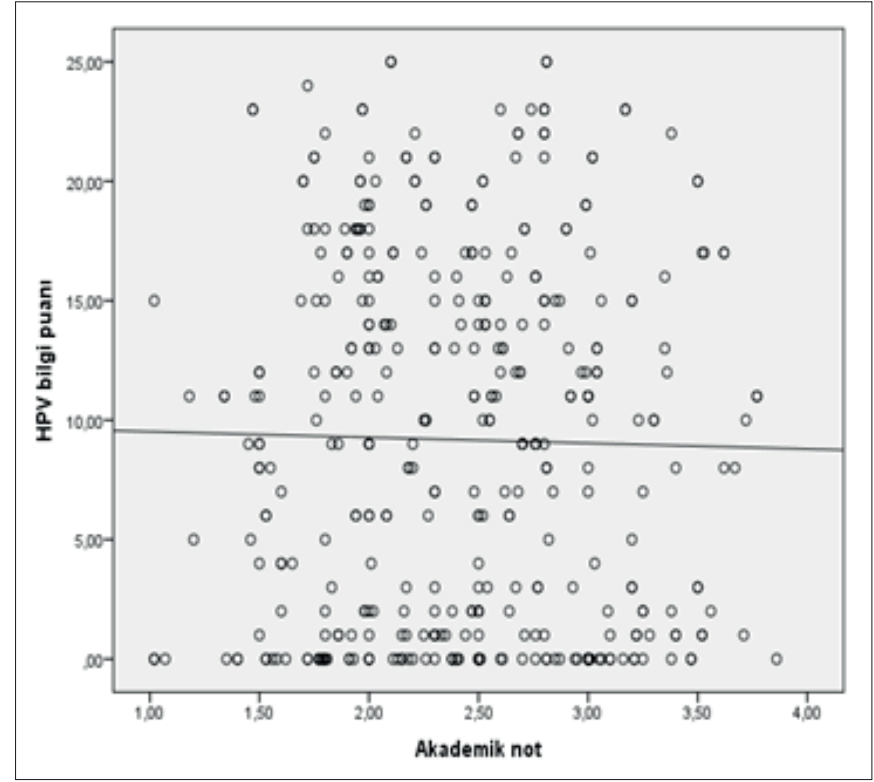

Grafik 1. Öğrencilerin akademik not ortalamaları ile HPV bilgi değerlendirme sorularından aldıkları puanların dağılımı. 


\section{TARTIȘMA}

Üniversite öğrencilerinin HPV ile ilgili bilgi düzeylerini değerlendirmeyi amaçladığımız çalışmamızda, öğrencilerin HPV hakkındaki bilgi düzeylerinin düşük olduğu görülmüştür. HPV ile ilgili yapılan birçok araştırmada bu bulguyu destekleyen sonuçlar elde edilmiştir. ${ }^{[15-18]}$ HPV'ye yönelik yapılan çalışmalara bakıldığında; sağlıkla ilgili alanlarda öğrenim gören genç grubun yarıdan fazlası HPV konusunda bilgi sahibi olduğunu ifade ederken ${ }^{[19-22]}$, üniversite geneli ve sağlık dışı alanlarda eğitim gören gençlerde ise \%15-40 arasında HPV'ye yönelik bilgisinin olduğu ifade edilmiştir. [5, 23-25] Bu çalsşmada HPV ile ilgili olarak en çok doğru bilinen bilgi sorusu "Genital bölgede hijyenik olmayan işlemler HPV bulaş riskini artırır" iken, en çok yanlış bilinen ise "HPV enfeksiyonu doğurganlığı doğrudan etkilemez" bilgi sorusu olmuştur. Tarwireyi ve ark. yaptıkları bir çalışmada hemşirelerin yarıdan fazlasının (\%67) serviks kanseri ile ilgili bilgilerinin yetersiz olduğunu, \%86,6'sınınHPV'ninserviks kanseri için risk faktörü olduğunu bilmediklerini ${ }^{[26]}$, Pınar ve ark. çalışmalarında hemşirelerin \%55,2'sinin "HPV kadın üreme organlarında kanser yapabilir" önermesine "evet" dediklerini belirlemişlerdir. ${ }^{[27]}$ Riskli grupta olan bireylere eğitim veren hemşirelerin bu sorulara doğru yanıt verme oranlarının yüksek olması sevindiricidir.

Sağlık Yüksekokulu öğrencilerinin HPV hakkındaki bilgi düzeylerinin diğer fakültelerde öğrenim görmekte olan öğrencilere göre anlamlı bir şekilde daha yüksek olduğu saptandı $(\mathrm{p}<0,05)$. Öğrencilerin HPV hakkında bilgilerinin YÜKSEK olması sağlık alanında eğitim görmeleri ile ilgili olabilir. Konuyla ilgili öğrenciler ve sağlık personeli ile yapılan bazı çalışmalarda HPV'nin yol açtığı hastalıkları bilen katılımcıların oranının yüksek olduğu görülmüştür. $[9,13,15,17,28,29]$ Çalışma grubunda Sağlık Meslek Lisesi mezunu olanların HPV bilgi düzeyi, diğer liselerden mezun olanlara göre anlamlı bir şekilde daha yüksektir $(\mathrm{p}<0,05)$.

HPV virüsünün serviks kanserine neden olduğunu bilenlerin HPV bilgi düzeyi, bilmeyenlerden daha yüksek bulunmuştur $(\mathrm{p}<0,05)$. Toplumda görülen serviks kanserine bağlı kadın ölümleri toplumun konu hakkında bilinçlendirilmesiyle azaltılabilir. Ancak yapılan çalışmalar toplumun önemli bir oranının serviks kanserine neden olan risk etmenlerini bilmediğini göstermektedir. Risk etmenlerinin bilinmemesi; korunmaya ve tanı-tedavi yöntemlerinin kullanılmasına engel olmaktadır. ${ }^{[30,31]}$

Çalışma grubunda HPV aşısı hakkında önceden bilgi sahibi olanların HPV bilgi düzeyi, olmayanlardan daha yüksektir $(p<0,05)$. HPV aşısı ile aşılama öneren sağlık çalışanlarının oranlarını Daley ve ark. yaptıkları çalışmada $\% 89,8^{[32]}$,
Esposito ve ark. \%84,8 olarak bildirdikleri görülmüştür. [33] Bizim çalışmamızda ise HPV asısını öneren hemşirelik öğrencilerinin oranının $(\% 83,3)$ literatürle uyumlu olarak yüksek olduğu görülmüştür. Bu sonuçlar sağlık çalışanlarının HPV aşısını yüksek oranlarda önermeleri, farklı ülkelerde de olsalar, asılama konusundaki duyarlılıklarını, aşılama ile serviks kanseri ve HPV enfeksiyonu ile ilişkili diğer lezyonlarda azalma olabileceğine inandıklarını gösterebilir.

Çalışmamızda HPV aşısı olmak isteyen öğrencilerin HPV bilgi düzeyi, aşı olmak istemeyenler göre daha yüksek saptanmıştır ( $\mathrm{p}<0,05)$. Caskey ve ark.'nın (2009) yaptığı çalışmada ise; aşıyı kabul eden kızöğrencilerin \%89'u, kabul etmeyenlerin ise \%83'ünün HPV'nin servikal kansere neden olduğunu bildikleri belirtilmiştir. ${ }^{[34]}$ Başka bir araştırma sonucuna göre ise aşı yaptırmış olan öğrencilerin $\% 71,2$ 'si HPV'nin servikal kansere neden olduğunu bildiğini, aşı yaptırmamış olan öğrencilerin ise \%59,2'sinin HPV'nin servikal kansere neden olduğunu bildiğini belirtmiştir. ${ }^{[35]}$ Öğrencilerin HPV'nin servikal kansere neden olduğunu bilme oranlarının yüksek olması medya aracılığı ile aşının tanıtımına yönelik haberlerden ve bir kısmının da okulda verilen bilgilerden öğrenmiş olabileceği düşünülmektedir. Marlow ve ark.'nın (2009) yaptığı araştırmada; kız öğrencilerin \%71,9'u aşının kendisini servikal kanserden koruyacağına inandığı için aşı yaptırmak istediği bildirilmiştir. ${ }^{[36]}$ Amerika Birleşik Devletleri'nde kolej öğrencileri arasında yapılan bir araştırmada öğrencilerin $\% 74$ ü aşının güvenilir olduğunu düşündükleri için aşı yaptırmak istediklerini belirtilmiştir. ${ }^{[37]} \mathrm{Bu}$ araştırmada da diğer araştırmalarla benzer nitelikte bulgular elde edilmiştir. Kız öğrencilerin büyük bir çoğunluğu servikal kansere karşı koruyucu olacağı için aşı yaptırmak istemektedir.

Yetişkinlerin HPV'yi duyma oranlarının yetersizliği de düşünülünce toplumumuz, serviks kanserinin bulaşıcı bir virüsten kaynaklandığını ve bulaş yollarını yeterince bilmemektedir. HPV enfeksiyonu hakkında farkındalığın olmaması aşı gibi korunma yöntemlerinin gerekliliği algısını azaltacaktır. Gençler hastalıklar konusunda daha umursamaz ve cesur davranışlar sergileyebilirler. ${ }^{[24]}$ Lise düzeyinde eğitim alan kızlar ve anneleriyle yapılan bir çalışmada anne öğrenim düzeyi lise ve üzeri olan kı öğrencilerin HPV bilgi düzeylerinin daha fazla olduğu bulunmuştur. ${ }^{[25]}$ Gençlerin bilgi sahibi olması için önce anne ve babaların bilgi düzeylerinin artırılması gerekmektedir.

\section{SONUÇ}

Bu çalışmada öğrencilerin HPV hakkındaki bilgi düzeylerinin düşük olduğu görülmüştür. Sağlık Meslek Lisesi mezunu olanların ve Sağlık Bilimler Fakültesi öğrencilerinin 
HPV bilgi düzeyleri diğerlerine göre daha yüksektir. HPV hakkında önceden bilgi sahibi olanların HPV bilgi düzeyleri yüksektir. Öğrencilerin akademik not ortalamaları ile HPV bilgi düzeyleri arasında bir ilişki yoktur. Öğrencilerin HPV ile ilgili bilgi düzeylerinin arttırılması için üniversitelerde sağlıkla ilgili dersler kapsamında HPV ile ilgili olarak yer verilmesi yararlı olacaktır. Ayrıca Sakarya Üniversitesi öğrencilerine yönelik olarak HPV hakkında belli aralıklarla bilgilendirme çalışmalarının yapılması bu konudaki duyarlılığı ve farkındalığı arttıracaktır.

\section{Sınırlılıklar}

Çalışmanın kesitsel tipte bir araştırma olması, çalışmanın sadece bir üniversitede yapılmış olması çalışmanın sınırlılıkları arasında sayılabilir.

\section{Teșekkür}

Çalışmamıza katılmaya gönüllü olan öğrencilere teşekkür ederiz.

\section{Etik Kurul Onayı}

Çalışma, Sakarya Üniversitesi Tıp Fakültesi Etik Kurulu tarafından onaylandı.

(onay tarihi ve sayısı: 17.09.2014/30579404/044).

\section{Hakem Değerlendirmesi}

Dış bağımsız.

Çıkar Çatışması

Yazarlar çıkar ilişkisi olmadığını beyan etmişlerdir.

Finansal Destek

Herhangi bir mali destek alınmamıştır.

\section{Ethics Committee Approval}

The study was approved by Sakarya University Faculty of Medicine Ethics Committee. (date and number of approval: 17.09.2014/30579404/044).

\section{Peer-review}

Externally peer-reviewed.

\section{Conflict of Interest}

No conflict of interest was declared by the authors.

Financial Disclosure

No financial support has been received.

\section{KAYNAKLAR}

1. Crossley B, Crossley J. A review of theuse of Human Papillomavirus (HPV) in cervical screening. Br J Biomed Sci 2017;74:105-9. [CrossRef]

2. Hacımustafaoğlu M. İnsan Papilloma Virus (HPV) Aşıları. Çocuk Derg 2007;7:27-30.

3. Walboomers JM, Jacobs MV, Manos MM, Bosch FX, Kummer JA, Shah KV, et al. Human Papillomavirus is a necessary cause of invasive cervical cancer worldwide. J Pathol 1999;189:12-9. [CrossRef]

4. Monsonego J, Bosch FX, Coursaget P, Cox JT, Franco E, Frazer I, et al. Cervical cancer control, priorities and new directions. Int J Cancer 2004;108:329-33. [CrossRef]

5. Giuliano AR, Harris R, Sedjo RL, Baldwin S, Roe D, Papenfuss $\mathrm{MR}$, et al. Incidence, prevalence, and clearance of type- specific Human Papillomavirus infections. The Young Women's Health Study. J Infect Dis 2002;186:462-9. [CrossRef]
6. Başli M, Aksu H, Toptaş B. Bir üniversitede öğrenim gören sağlık yüksekokulu öğrencilerinin Human Papilloma Virüs ve HPV aşısı ile ilgili bilgi ve görüşleri. Ankara Sağlık Bilimleri Derg 2019;8:1-17. https://dergipark.org.tr/tr/download/articlefile/736473

7. Kurtoğlu E, Alper Gürz A. Serviks Kanseri Epidemiyolojisi. Turkiye Klinikleri J Gynecol Obst - Special Topics 2014;7:1-4. https://www.turkiyeklinikleri.com/article/en-serviks-kanseriepidemiyolojisi-69419.html

8. Türkiye Kanser İstatistikleri. [Online] Türkiye Halk Sağlığ Kurumu, 2014. https://hsgm.saglik.gov.tr/tr/kanser-istatistikleri/ yillar/2014-yili-turkiye-kanser-istatistikleri.html

9. Çeşmeci Y, Köylü B, Sulaiman J, Sancak E, Şenel S, Baki HE, et al. İnternlerin gözünden HPV enfeksiyonları ve HPV aşısı. Türk Jinekolojik Onkoloji Derg 2015;3:85-92. https://dergipark.org.tr/ $\mathrm{tr} /$ download/article-file/439557

10. Cangöl E, Sögüt S, Kahyaoğlu Süt H, Küçükkaya B. Hemşirelik bölümü öğrencilerinin HPV aşısına yönelik bilgi ve tutumları. J Hum Sci 2019;16:1-12. [CrossRef]

11. Şahbaz A, Erol O. HPV aşı uygulamaları. J Turk Soc Obstet Gynecol 2014;2:126-30. [CrossRef]

12. Güvenç G, Akyüz A, Seven M. Hemşirelik yüksekokulu Öğrencilerinin Human Papillomavirüs enfeksiyonu ve aşıları ile ilgili bilgi ve tutumlarının belirlenmesi. Gülhane Tip Derg 2012;54:104-10. https://app.trdizin.gov.tr/makale/ TVRRd05UVXINZz09/hemsirelik-yuksek-okulu-ogrencilerininhuman

13. Kunt İşgüder Ç, Oktay G, Yılmaz Doğru H, Delibaş İB, Özsoy AZ, Yıldız Çeltek N, Bulut YE. Sağlık yüksekokulu öğrencilerinin HPV aşısı bilgi düzeyinin değerlendirilmesi. J Contemp Med 2017;7:1-7. [CrossRef]

14. Güdücü N, Gönenç $G$, İşçi $H$, Başgül Yiğiter A, Dünder İ. Awareness of Human Papillomavirus, cervical cancer and HPV vaccine in healthcare workers and students of medical and nursing schools. J Clin Exp Invest 2012;3: 318-25. [CrossRef]

15. Barnard M, George P, Perryman ML, Wolff LA. Human Papillomavirus (HPV) vaccine knowledge, attitudes, and uptake in college students: Implications from the precaution adoption process model. Plus One 2017;12:e0182266. [CrossRef]

16. Kızılca Çakaloz D, Öztürk G, Çoban A, Karaçam Z. Ebelik öğrencilerinin servikal kanser ve HPV aşısı hakkında bilgi ve düşüncelerinin belirlenmesi. Adnan Menderes Üniversitesi Sağlık Bilimleri Fakültesi Derg 2017;2:55-64. https://dergipark.org.tr/tr/ download/article-file/489419

17. Erbaydar N, Çilingiroğlu N, Keskin C, Altunbaş M, Arslanoğlu E, Aydın O, et al. Human Papilloma Virus aşısı bir üniversite hastanesi hemşireleri için ne ifade ediyor? Hacettepe Üniversitesi Hemşirelik Fakültesi Derg 2016;3:16-27. https://dergipark.org.tr/ tr/download/article-file/330436

18. Wilson KL, Lee Smith M, Rosen BL, Pulczinski JC, Ory MG. HPV vaccination status and mandate support for school-aged adolescents among college females: A descriptive study. J Sch Nurs 2017;33:232-45. [CrossRef]

19. Chelimo C, Wouldes TA. Human Papillomavirus knowledge and awareness among undergraduates in healthcare training in New Zealand. N Z Med J 2009;122:33-45. https://pubmed.ncbi.nlm. nih.gov/19859090/

20. González LMR, Canto-Peréz JL, Puerto-Solís, M. Cervical cancer screening: knowledge among student workers in a rural area of Mexico. Quality Prim Care 2006;14:205-9. https://primarycare. imedpub.com/cervical-cancer-screening-knowledge-amongstudent-workers-in-a-rural-area-of-mexico.pdf 
21. Medeiros R, Ramada D. Knowledge differences between male and female university students about Human Papillomavirus (HPV) and cervical cancer: Implications for health strategies and vaccination. Vaccine 2010;29:153-60. [CrossRef]

22. D'Urso J, Thompson-Robinson M, Chandler S. HPV Knowledge and Behaviors of Black College Students at a Historically Black University. J Am College Health 2007;56:159-63. [CrossRef]

23. Durusoy N, Yamazhan M, Taşbakan MI, Ergin I, Aysin M, Pullukçu H, et al. HPV Vaccine Awareness and Willingness of First-Year Students Entering University in Western Turkey. Asian Pac J Cancer Prev 2010;11:1-7.

24. Hoque E, Hoque M. Knowledge of and attitude towards cervical cancer among female university students in South Africa. South Afr Epidemiol Infect 2009;24:21-4. [CrossRef]

25. Hoque ME. Cervical cancer awareness and preventive behaviour among female university students in South Africa. Asian Pac J Cancer Prev 2010;11:127-30. [Erişim]

26. Tarwireyi F, Chirenje ZM, Rusakaniko S. Cancer of the cervix: knowledge, beliefs and screening behaviours of health workers in Mudzi District in Mashonal and East Province, Zimbabwe. Cent Afr J Med 2003;49:83-6. https://pubmed.ncbi.nlm.nih. gov/15214279/

27. Pınar G, Algıer L, Çolak M, Abbasoglu A. Hemsirelerin serviks kanseri ve HPV aşısı hakkındaki bilgi düzeyleri. Türk Jinekolojik Onkoloji Derg 2007;10:94-8. https://dergipark.org.tr/tr/ download/article-file/439202

28. Özakar Akça S, Selen F, Büyükgönenç L. Hemşirelerin Human Papilloma Virüs (HPV) enfeksiyonu ve HPV aşısı hakkındaki bilgi düzeyleri: Eğitim ve araştırma hastanesi örneği. Hemşirelikte Eğitim ve Araştırma Derg 2016;13:116-21. [CrossRef]

29. Demirel Bozkurt Ö, Hadımlı A, Şen E, İkde Öner Ö, Öztürk Can H. Hemşirelik öğrencilerinin human papilloma virüs (HPV) enfeksiyonu ve aşısına yönelik bilgi ve görüşleri: bölgesel farklılıklar. Uluslararası Hakemli Kadın Hastalıkları ve Anne Çocuk Sağlığı Derg 2016;3:23-48.
30. Clifford GM, Smith JS, Plummer M, Munoz N, Franceshi S. Human papilloma virus types in invasive cervical cancer worldwide: A meta-analysis. Br J Cancer 2003;88:63-73. [CrossRef]

31. Munoz N, Bosch FX, de Sanjose S, Herrero R, Castellsagué X, Shah KV, et al. Epidemiologic classification of human papilloma virus types associated with cervical cancer. $\mathrm{N}$ Engl J Med 2003;348:518-27. [CrossRef]

32. Daley MF, Liddon N, Crane LA, Beaty BL, Barrow J, Babbel C, et al. A national survey of pediatrician knowledge and attitudes regarding human papillomavirus vaccination]. Pediatrics 2006;118:2280-9. [CrossRef]

33. Esposito S, Bosis S, Pelucchi C, Begliatti E, Rognoni A, Bellasio, $\mathrm{M}$ et al. Pediatrician knowledge and attitudes regarding human papillomavirus disease and its prevention. Vaccine 2007;25:643746. [CrossRef]

34. Caskey R, Lindau ST, Alexander GC. Knowledge and early adoption of the HPV vaccine among girls and young women: results of a national survey. J Adolesc Health 2009;45:453-62. [CrossRef]

35. Meghani H, Dubey V, Kadri O, Mathur A, Cameron J, Beckermann, K. Factors Contributing to Uptake of the Publiclyfunded HPV vaccine in Toronto. Int J Infect Dis 2010;14:e452. [CrossRef]

36. Marlow L, Waller J, Evans R, Wardle J. Predictors of interest in HPV vaccination: A study of British adolescents. Vaccine 2009;27:2483-8. [CrossRef]

37. Boehner CW, Howe SR, Bernstein DI, Rosenthal SL. Viral sexually transmitted disease vaccine acceptability among college students. Sexually Transmitted Dis 2003;30:774-8. [CrossRef] 